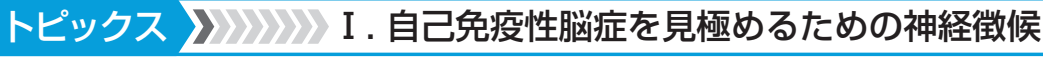

\section{自己兔疫性譄症を 見極めるための神経徴候}

\section{要 旨}

一部の自己免疫性脳症と精神疾患は臨床徴候が類似することが多く, し ばしば誤って診断されている. 従来の神経診察法のみで正確に診断するこ とは難しく, 脳がびまん性に障害された場合の神経徵候を理解するという 視点が必要である、見極めるためには詳細な問診と神経診察が重要であ り, SPECT (single photon emission computed tomography), 甲状腺 自己抗体ならびに抗GluR抗体測定が診断に有用である.

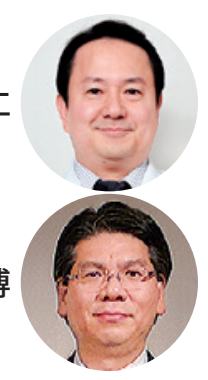

〔日内会誌 $106 ： 1542 １ 549 ， 2017$ ]

Key words 甲状腺自己抗体，びまん性脳障害，give-way weakness，多発性脳血流低下，抗GluR抗体

\section{はじめに}

自己免疫性脳症と精神疾患は臨床症状が類似 することが多く，しばしば䛊って診断されてい る。代表的な自己免疫性脳症の1つである抗 NMDA（N-methyl-D-aspartate）受容体脳炎は若 年女性に多く発症する脳炎だが，統合失調症様 の精神症状で発症することが多く，頭部MRI (magnetic resonance imaging) で異常所見を認 めない例も多い。患者の多くは抑うつ, 不安等 の精神症状を自覚し，まずは精神科を受診す る. その後, 興奮, 幻覚, 妄想, 不随意運動等 の統合失調症様の症状が出現し, その後, 無反 応期に移行するとされる。以前では，抗NMDA 受容体脳症は急性発症の統合失調症として取り 扱われてきたようであるが，医学の進歩により
精神疾患の原因が明らかになった代表的疾患と 言える. 加えて, 統合失調症の精神症状は従来 から脳のNMDA受容体機能が低下することが原 因で, これら2つの疾患は原因が異なるものの, 共通した病態が関与しているのではないかと考 えられるようになってきている1). 当初は, 脳 疾患が精神疾患と考えられていたという報告は 多数にのぼり, 精神科的な症状を呈する患者の 中に自己免疫的機序による器質的脳疾患が原因 である患者が多数含まれている可能性は高い. 我々は，過去 5 年で 100 例近くの自己免疫性脳 症の症例を経験し, 自己免疫性脳症をより正確 にピックアップするための知見を得たので，そ のポイントについて記載する. 


\section{1. 誤って診断されることが多い 自己免疫性脳症の種類と臨床情報}

橋本脳症は甲状腺自己抗体に関連した脳症で あるが，はっきりとした病態は明らかになって いない。一般的には甲状腺自己抗体が陽性で, 意識障害・精神症状, 認知機能障害, 病攣発作 等を伴ってステロイドへの反応が良好な疾患群 を指す。初期の報告では，意識に変容を来たす ような重症例の報告が多く，稀な疾患と考えら れていた. しかし, 橋本脳症は従来考えられて いたより日常診療に多く潜んでおり, 軽症例も 多数存在することがわかった ${ }^{2)}$. 我々の施設で は過去3年間に 19例の橋本脳症の患者を診断し ている。これらの患者の多くは不定愁訴と診断 され，対症療法のみで経過をみられているか， 身体表現性障害のような精神疾患と診断されて 心療内科か精神科に紹介されていた。診断のた めには，まず本疾患を疑って甲状腺自己抗体を 測定し, ステロイドへの反応性を確認しなくて はならないため，正確に診断されずに見逃され ていることが多い.

近年, 子宮頸がんワクチン（HPV（human papillomavirus）ワクチン）接種後に自己免疫性 脳症を発症する例の報告もされている。一般的 には, ワクチンが急性散在性脳脊髄炎（acute disseminated encephalomyelitis : ADEM）や血管 炎のような自己免疫疾患を引き起こすことは既 に知られている3). HPVワクチン接種後の脳症 は経過観察のみで改善する軽症例から強力な免 疫療法を必要とする重症例までさまざまである が，一般には重篤な意識障害を発症する例は少 なく, 脱力, 歩行障害, 疼痛等の異常感覚, 不 随意運動, 精神症状, 倦怠感, 睡眠障害, 発汗 障害やPOTS (postural orthostatic tachycardia syndrome）等，多彩な神経症状を呈し，社会問 題ともなっている。これらは従来使用されてい る神経学的診察法では解釈困難であるため, 身 体表現性障害, 疼痛性障害等の精神疾患と診断
されている例が多く，実際に多くの患者が心療 内科の受診を指示されている. 多くは心療内科 的治療では改善しないため, 徐々に増悪してか ら我々の施設に辿りついており，その症例数は 過去 3 年間で 40 例以上にのぼる. HPV 16, 18 ワクチン接種後の神経症状には多様な意見があ るが, 我々独自の解析では何らかの自己抗体を 有しており, 免疫抑制治療に反応するケースや 改善するケースも確認されている ${ }^{4)}$. 今後の議 論を注視したい.

その他, 甲状腺自己抗体やワクチンとの関連 はなく, 脳炎特異的な自己抗体は陰性だが, 何 らかのトリガー（交通事故, 感染, 手術, 薬物, 予防接種, 妊娠出産）をきっかけに自己免疫性 脳症を発症する例もある. 我々の施設での過去 3 年間の検討ではこのような原因不明の自己免 疫性脳症は決して珍しくない。ここには様々な 原因の脳症が含まれると思われるが, 免疫療法 で明らかに改善した患者を検討したところ，重 篤な意識障害を認めた症例は少数だが，多くの 患者で四肢脱力と異常感覚を認め, その他にも 振戦や不随意運動, 失語, 記憶障害等の神経症 状を認めていた。ほとんどの患者で頭部MRIで は特異的な異常所見はなく, 髄液一般検査も正 常であった。一見不定愁訴と判断されがちな患 者の中に自己免疫性脳症の患者が潜んでいるこ とになる。

以上の各種脳症の類似点としては, 脱力があ る場合, give-way weaknessを伴うことが多い. 我々はgive-way weaknessは「力を込めるように 指示した時に, 持続的に力を込めることが出来 ない状態」と定義した。実際には，力を継続し て入れることができないため, 筋力の強弱が繰 り返されて不安定な筋力となっている。他には 神経分布に沿わなかったり寛解増悪を繰り返し たりする非典型的な異常感覚, 原因不明の不随 意運動や倦急感が挙げられる.これらの症候は 従来の精神科的神経診察法に照らし合わせる と，偽神経症状，すなわち心因性疾患の症状と 
いうことになってしまうが, その解釈は誤りで あり，実際には免疫療法が有効な自己免疫性脳 症が多数含まれている5).我々の経験した橋本脳 症の 1 例と交通事故後に発症した自己免疫性脳 症の 1 例について提示し, 自己免疫性脳症の症 候とその想定されるメカニズムについて述べる.

\section{2. 症例呈示}

\section{Case 1）橋本脳症の1例}

45 歳, 女性. 既往にBasedow病. X年 1 月, 近 医でインフルエンザの予防接種直後にショック 状態に陥り, その回復後に頭痛や咽頭部違和 感, 目の見え方がおかしい等の症状が出現, 数 時間後には頭痛と下顎部の不随意運動が出現し 搬入された. 頭部MRI検査や髄液一般検査では 異常所見を認めなかったため, 予防接種時の疼 痛による心因反応として経過観察となったが, 頭痛と不随意運動は持続した. その後, 右上下 肢脱力, 右下肢異常感覚等が出現したため, 3 月に当院入院となった。症状はさらに増悪して おり, 脱力は四肢全体にみられ, give-way weakness様であり, 症状は変動した。右半身異常感 覚を認めたが，時に左に移動する等再現性に乏 しかった。 口周囲と右上肢に振戦がみられた が，他に集中させると消失する等非典型的で あった．以上の神経所見は従来の考え方だと心 因性を示唆するものであったが，自己抗体検索 を行ったところ, 抗TPO抗体陽性, 抗サイログ ロブリン抗体陽性, 抗 $\mathrm{N}$ 末端 $\alpha$-エノラーゼ抗体 （抗NAE抗体）陽性だった. 免疫療法を行ったと ころ, 前述の症状は徐々に軽快し, 日常生活に 支障のない状態まで回復した。本患者の画像検 査ではSPECTで大脳皮質表面の多発性の血流低 下を認めた（図 1).

Case 1 は予防接種直後のショック状態という 明らかなトリガーがあるものの, 理解困難な神 経症状が続発したため, 心因反応とされた症例
である。本例は運動, 感覚, 不随意運動等複数 の経路がびまん性に障害されており，びまん性 脳障害が疑われる。 また, 抗NAE抗体という橋 本脳症に特異性の高い自己抗体が検出され, 免 疫療法により改善した。このような橋本脳症の 患者は必ずしも甲状腺疾患を有しないが, 橋本 病やBasedow病に合併する例も多い.

\section{Case 2）交通事故後に発症した} 自己免疫性脳症の 1 例

46 歳, 男性. $X-7$ 年に交通事故で受傷. 事 故後より両下肢脱力感, 左上肢異常感覚があ り, 頸椎MRIで OPLL（ossification of posterior longitudinal ligament）を認めたため, 外傷性の 頸髄損傷と診断された。四肢脱力や下肢異常感 覚が徐々に増悪したが, 頸髄病変の増悪もない ため, 詐病を疑われた.リハビリ入院を繰り返 して経過をみられていたが, X-6年より話しづ らさが出現, 神経疾患の確認のため, X年に当 科紹介受診となった。当科受診時には症状はさ らに増悪しており，右半身優位の四肢筋力低下 を認め，それぞれgive-way weaknessを認めた。 移動はほとんど車椅子を用いていた。四肢末梢 や顔面のぴりぴりした異常感覚, 右下肢の温痛 覚低下, 下肢深部覚低下等神経分布にあわない 感覚障害を認めた。 Babinski反射は両側陽性, 歩行は右下肢に強い病性歩行だった。普段の会 話はおおよそ流暢であるのに，物品呼称を間違 えることがある等喚語困難を認めた。髄液検査 では異常を認めず，頭部MRIでは頭頂葉皮質の 非特異的な軽度の萎縮を認めた. 以上の経過か らは頸髄障害と精神疾患の合併を疑われやすい が，ステロイド投与及び免疫吸着療法を行った ところ喚語困難は消失し, 10 m歩行の秒数は 95 秒 $\rightarrow 38$ 秒と劇的に改善した。本症例でも ${ }^{123} \mathrm{I}-$ IMP SPECTで左前頭前野から前頭葉運動野, 下 前頭回領域, 側頭葉内側, 頭頂葉感覚野にかけ て多発性の血流低下を認め, 左右差を認めた(図 2). 本症例は甲状腺関連抗体, 膠原病関連抗体, 抗神経抗体等全て陰性だったが, 後日, 䯣液中 

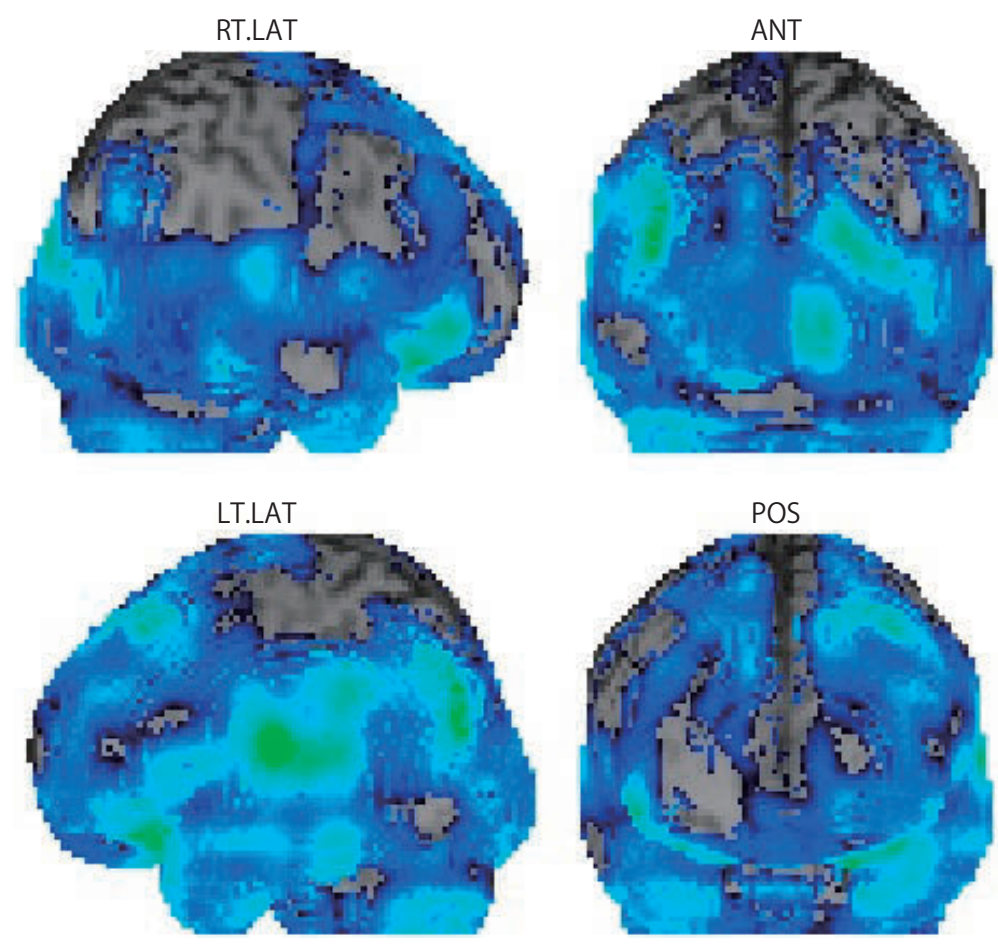

図 1 Case1 の 99mTc-ECD SPECT eZIS統計解析画像

血流低下部位に着色しており，大脳皮質で多発性に広範な血流低下部位がみ られている.

の抗グルタミン酸受容体抗体 (抗GluR抗体) が 陽性であることが判明した。患者は現在も維持 療法を継続しており，仕事に復帰することもで きている.

Case 2 は 7 年にわたって詐病の合併と誤認さ れ，対症療法とリハビリテーションのみで経過 をみられてきた症例である。交通事故後，次第 に増悪してくるこのような症例は, 事故後の保 障の問題も絡んで詐病を疑われがちであるが, 実際には本症例のような自己免疫性脳症の患者 が含まれている，単純に頸椎病変では説明困難 な症状も多く, 感覚異常も顔面も含女解剖学的 分布に一致せず，言語・思考能力も低下してお り,びまん性脳障害の合併が示唆された。我々 は交通事故というトリガーと特徴的な神経所見 から自己免疫性脳症と診断, 適切な免疫療法を
行った。頭部MRIでの頭頂葉皮質の萎縮は脳症 の長期経過の影響が疑われる.

\section{まとめ}

上記の 2 症例に限らず, 我々の経験した自己 免疫性脳症に共通する所見としては頭部MRIで 異常所見を認めない症例が多く, 髄液一般検査 でも細胞数や蛋白は正常範囲であることが多 い. 従って, これらが正常であるからといって, 脳症の可能性を否定することは誤った診断につ ながる。自己免疫性脳症の診断のためには, び まん性脳障害により複数の脳の系統が障害され ていることを見つけて疑うことが重要である. MRI所見や髄液所見に頼りすぎると見逃してし まうこととなる。主な神経症状として筋力低下 


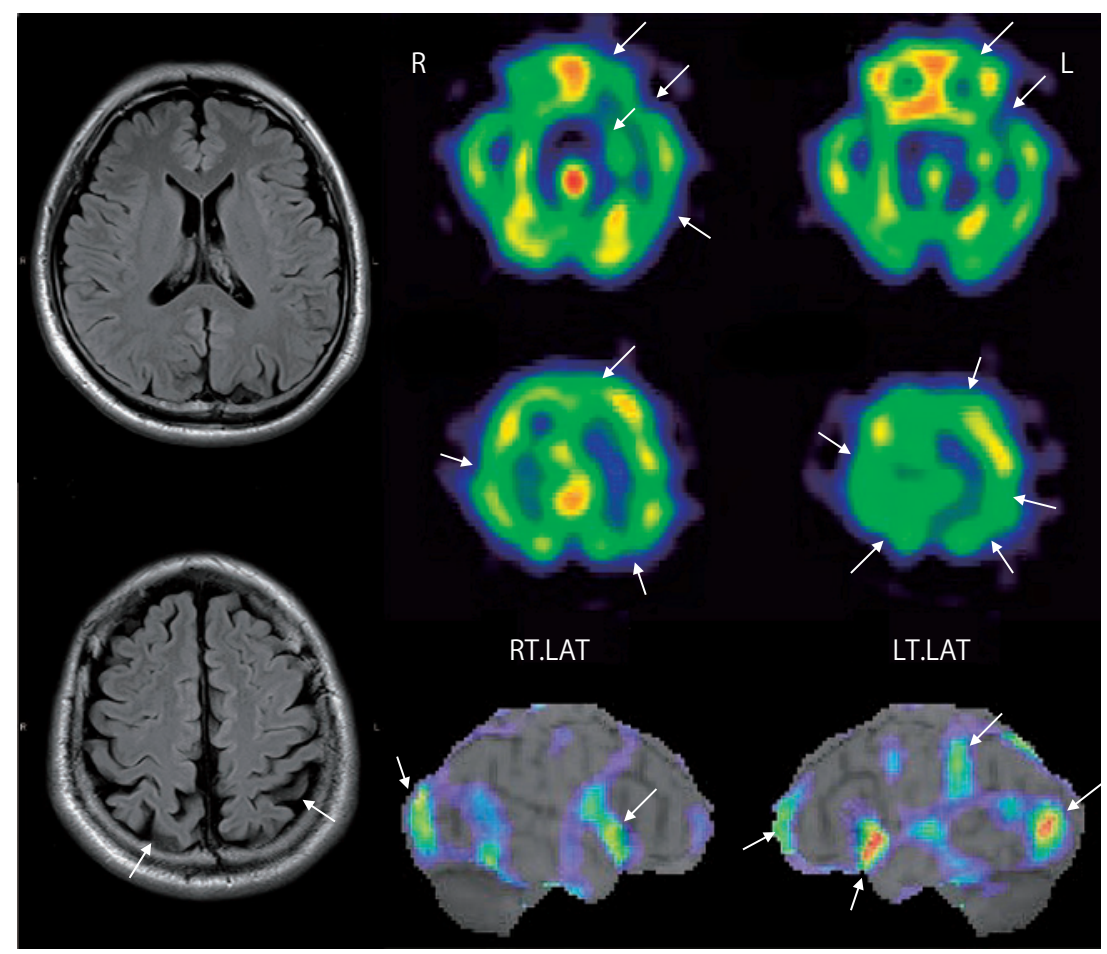

図2 Case2の画像所見

左：頭部MRI 頭頂葉後部で大脳皮質の萎縮がみられる.

右上：123-IMP SPECT 血流低下部位に矢印。大脳の多発性の血流低下，左右差がみ られている.

右下：3D-SSP統計解析画像 血流低下部位に着色しており，大脳皮質の多発性血流 低下が確認できる.

があるが，脳卒中等と異なり，直接錐体路が障 害される例は少なく，運動のプログラミング異 常を示す例が多い，筋力低下の存在する患者の 訴えを傾聴していると，力の入れ方がわからな いと答えることがあり, give-way weaknessは通 常の麻痺とは異なり, 力を上手く調整できない 状態を示していると考えられる。我々は筋収縮 を起こすための持続的な神経発火が上手くいか ずに途切れてしまうような機序を想定してい る. 運動に関するプログラミングは主に前頭葉 皮質の補足運動野から基底核を経由する脳内回 路が担当しているとされており, 患者のSPECT 所見で示される障害部位と矛盾しない結果で あった。
我々は, 自己免疫性脳症の症候をより理解し やすいように，びまん性脳障害の神経症候学を 提案している。びまん性脳障害とは, 脳機能が びまん性, 散在性に濃淡を持った形で障害され る機序で, 神経線維連絡や神経細胞の活動が制 限され，脳障害を引き起こすような機序で起こ る症状を念頭に置いている。例えば，橋本脳症 は, 病理学的には微小血管炎が報告され, 大脳, 脳幹小脳等様々な部位が小血管周囲炎の影響に より機能が低下しており, SPECTではその障害 部位がある程度捉えられている。びまん性に脳 が障害されると重症例では意識障害が出現する が，比較的軽症な例は記憶回路障害に基づく 様々な形の記憶障害, 思考遅延, 言葉の想起困 

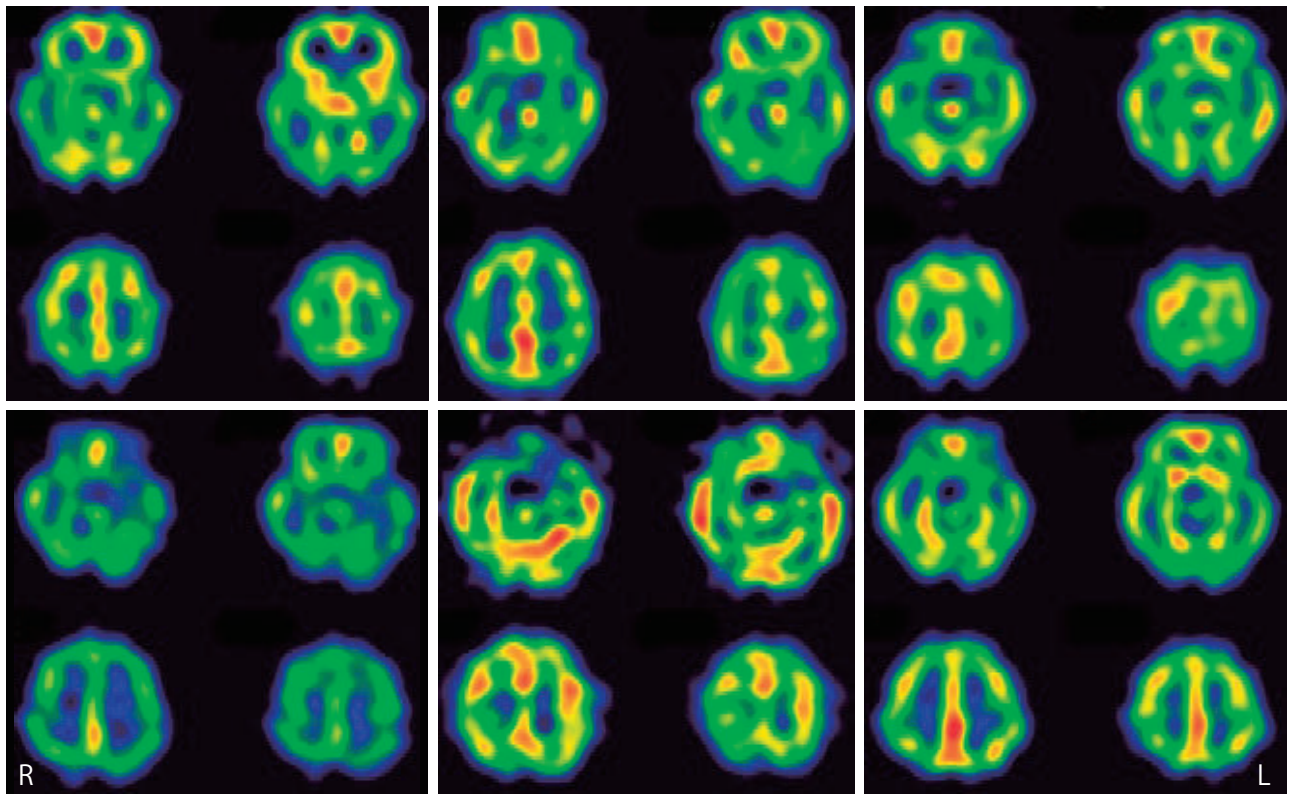

図3 自己免疫性脳症6症例の 123 |-IMP SPECT所見

どの症例も共通して大脳の多発性の血流低下，左右差を認めている.

難, 運動プログラム障害による巧緻運動障害, 筋力の持続力低下, 歩行障害, 振戦, 見たこと もないような不随意運動, 感覚分布に合わない 疼痛, 感覚低下, 振動覚低下, 視覚異常, 羞明, 視床下部障害に由来する睡眠や覚醒の障害, 月 経異常，自律神経障害等が出現する．脳障害に 基づくと思われる神経症状を複数の系統につい て持っていると,びまん性脳障害と判定できる.

脳症と自己抗体の関連については, 抗gACh-R 抗体陽性の脳症やGABAA受容体抗体陽性脳症 等, 新たな知見が次々と生まれており, 自己免 疫性脳症の病因や病態が多様であることがわ かってきている6,7).これまで病態が不明であっ た脳症の原因も今後次々に判明してくるものと 思われる. 自己免疫性脳症を診断するための疾 患マーカーとしては, 現状ではSPECTが最も高 感度であった. 特徵的な ${ }^{123}$ I-IMP SPECTの所見を 呈示する (図3)。ほとんどの症例で大脳の多発 性でpatchyな血流低下を認め, 左右差を認める 例も多い。これらの血流低下所見は一過性では
なく, 複数回撮影した場合でも同様の傾向があ り，再現性がみられた。 また, Case 2で検出さ れた抗Glu-R抗体は多様な中枢神経疾患で検出 されることが知られているが, その病因として の意義に関しては結論が出ていない. この抗体 は免疫学的機序が病態に関与する神経疾患で幅 広く発現しており, むしろ疾患マーカーとして の意義が高いものと考えられている．高橋らの 解析では, HPVワクチン接種後自己免疫性脳症 で検討したところ, 髄液中の抗GluR抗体が高い 確率で陽性であることが示された8).

自己抗体による自己免疫性脳症の成立のため には免疫物質が産生された後に，何らかのトリ ガーが存在することが発症の契機となる例が多 いと考えられ, 病歴上これらに該当するような イベントがなかったかどうかを問診すること が, 自己免疫性脳症を疑ううえで重要である. また, 既存の自己免疫疾患 (多発性硬化症, 膠 原病等）が増悪と寛解を繰り返すことがあるの と同様, 自己免疫性脳症による神経症状も変動 
することが多い。症状が急速に増悪したり軽快 したり，非典型的な臨床経過を取る場合にも本 疾患を疑う必要がある。経過が非典型的な場 合，つい身体的疾患よりも精神的疾患を強く 疑ってしまうことが多いかもしれないが，注意 しなくてはならない。 また, 自己免疫性脳症で 障害される部位は必ずしも一定ではない。脳の あらゆる部位が障害される可能性があり，その 臨床症状は一定ではない。特に大脳が多発性に 自己免疫的に障害された場合の神経症状につい ては, 未知な部分が多く, その神経診察法は確 立されていない。そのため, 我々は過去に自己 免疫性脳症と診断した症例からその臨床的特徵 を集積し，それをもとに次の患者の診療に活か している.

我々がこれまで示してきたように, 自己免疫 性脳症の患者ではgive-way weaknessを伴う運 動障害, 非典型的な感覚障害, 非典型的な振戦 や不随意運動を示す例が多いことがわかった。 これらは従来, “心因性疾患を診断するための身 体診察所見”として記載されてきたものであ る。身体表現性障害の患者を解析した論文は多 数あるが, 身体表現性障害には確定診断のゴー ルドスタンダードがなく, 原因となる心因さえ 必須でないため，ほとんどの論文で診断が正し いかどうかもわからないのが現状である。過去 の機能的（心因性）片麻痺または一側性感覚障 害を呈する患者の長期経過を追った論文の報告 では，12.5年間のfollowで 83\%の患者において 症状が長期に残存していることがわかってい $\Xi^{9)}$. 我々の解釈では, 機能的（心因性）障害
と思われた症状は, 実は器質的障害が隠れてい る可能性がある. 身体表現性障害等の心因性疾 患と診断されてきた症例の一部または多数が実 は自己免疫性脳症であり, 少なくとも“心因性 疾患を診断するための身体診察所見”の特異性 は高くない. 救急の現場でもこの身体診察所見 を用いて身体表現性障害と診断する場合がある が，実際には患者に大変な迷惑をかけている ケースもあるものと思われる。日常診療で自己 免疫性脳症を正しく診断するためには, 非典型 で一見, 心因性疾患を疑わせる症例を診察した 場合であっても, 常に自己免疫性脳症の可能性 を捨てずに, 前述したような詳細な問診と診察 を行ったうえで, 可能性が高いと考えたときに はSPECTを施行し, 短期間でもステロイドなどの 免疫療法を試してみることがポイントである.

\section{おわりに}

我々の得てきた知見から自己免疫性脳症を見 極めるための神経徴候と検査所見の特徴を示し てきた。自己免疫性脳症の病因や病態は依然と して不明な点が多く, 精神・心因性疾患と類似 の神経徴候を示す例も多いため, 適切に診断さ れていない症例が多数存在することが予想され る。病因や病態が不明であるからといって治療 しなくてよいわけではない，我々は実地臨床に 招いて治療可能な自己免疫性脳症を見出す努力 をし，適切に治療しなくてはならない。

著者のCOI (conflicts of interest) 開示: 本論文発表内容 に関連して特に申告なし 
1）飯塚高浩：抗NMDA受容体抗体脳炎の臨床と病態. 臨床神経 $49: 774-778,2009$.

2）牧 美充，他：橋本脳症の診断と治療. Brain Nerve 68 : 1025-1033, 2016.

3) Felicetti $\mathrm{P}$, et al : Spontaneous reports of vasculitis as an adverse event following immunization : A descriptive analysis across three international databases. Vaccine $34: 6634-6640,2016$.

4）荒田 仁, 高嶋 博：ヒトパピローマウイルスワクチン接種後の神経障害 : 自己免疫性脳症の範疇から. 神経内科 $85: 547-554,2016$.

5）高畑克徳, 高嶋 博：自己免疫性脳症を見きわめるための新しい神経診察の提案一身体表現性障害との鑑別一. 神 経治療学 $33: 9-18,2016$.

6) Kuki I, et al : Autoimmune autonomic ganglionopathy in a pediatric patient presenting with acute encephalitis. Brain Dev 38 : 605-608, 2016.

7) Akman CI, et al : Limbic encephalitis associated with anti-GAD antibody and common variable immune deficiency. Dev Med Child Neurol 51 : 563-567, 2009.

8) Takahashi $Y$, et al : Immunological studies of cerebrospinal fluid from patients with CNS symptoms after human papillomavirus vaccination. J Neuroimmunol $298: 71-78,2016$.

9) Stone J, et al : The 12 year prognosis of unilateral functional weakness and sensory disturbance. J Neurol Neurosurg Psychiatry 74 : 591-596, 2003. 